\title{
Investigation of the Endothelial Response of the Super Elastic Braided Stent: An Experimental Evaluation
}

\author{
Süper Elastik Örgülü Stentin Endotel Yanıının İncelenmesi: Deneysel Bir Değerlendirme
}

\author{
Oguz Karahan ${ }^{1 *}$, Naci Öcal ${ }^{2}$, Tugce Sümer ${ }^{3}$, Erhan $\mathrm{Haflz}_{1}^{4}$, Emced Khal11 ${ }^{5}$ \\ 1.Medical School of Alaaddin Keykubat University, Department of Cardiovascular Surgery, AlanyalAntalya, Turkey \\ 2.Medicine Faculty of Kirikkale University, Department of Internal Medicine, Kirıkale, Turkey \\ 3.Veterinary Medicine Faculty of Kirikkale University, Department of Pathology, Kirıkkale, Turkey \\ 4.Medical School of Gaziantep University, Department of Cardiovascular Surgery, Gaziantep, Turkey
}

\section{ABSTRACT}

Aim: This study aimed to experimentally investigate the vascular biocompatibility of the new super elastic braided stents and ultrasonographically follow up the mid-term outcomes on the blood flow of stent-implanted vessels.

Method: After designation of the study steps, stents were implanted into the iliac arteries of two ewes. The preoperative and postoperative blood flow and local findings were noted. The ewes were inspected periodically for abnormal body changes, and the stent-implanted vessels were checked with Doppler ultrasonography. The subjects were sacrificed at six months, and the iliac arteries were examined histopathologically.

Results: During follow up an occlusive pattern was not observed in the stentimplanted vessels. The histopathological analysis revealed that both two stent area had no significant neointimal hyperplasia, despite sufficient re-endothelisation at the stent surface. Occlusive or stenotic patterns were not detected in both macroscopic and microscopic findings.

Conclusion: According to the mid-term findings, our results show that the new super elastic bare stents have good vascular biocompatibility with high patency rates.

Keywords: Super elastic bradied stent, vascular biocompatibility, neointimal hyperplasia, experimental model

\section{Öz}

Amaç: Bu çalışmada yeni süper elastik çıplak stentlerin vasküler biyoyararlanımının deneysel olarak araştıııması ve stent implante edilen damarların kan akışındaki orta dönem sonuçlarının ultrasonografik olarak izlenmesi amaçlandı.

Metot: Çalışma adımlarının belirlenmesinden sonra stentler iki koyun ilyak arterlerine implante edildi. Ameliyat öncesi ve sonrası kan akışı ve lokal bulgular kaydedildi. Denekler anormal vücut değişiklikleri açısından periyodik olarak takip edildi ve stent implante edilen damarlar Doppler Ultrasonografi ile kontrol edildi. Denekler 6 . ayda sakrifiye edildi ve iliak arterler histopatolojik olarak incelendi.

Bulgular: Takip sırasında stent implante edilmiş damarlarda herhangi bir oklüzyon paterni gözlenmedi. Histopatolojik analiz, stent yüzeyinde yeterli yeniden endotelizasyona rağmen, her iki stent bölgesinin de belirgin neointimal hiperplazi olmadığını ortaya koydu. Makroskopik veya mikroskopik bulgularda oklüzif veya stenotik patern saptanmadı.

Sonuç: Sonuçlarımız, yeni süper elastik çıplak stentlerin, orta dönem bulgularına göre yüksek açıklık oranları ile iyi vasküler biyoyararlıığa sahip olduğunu göstermiştir.

Anahtar kelimeler: Super elastic çıplak stent, vasküler biyouyumluluk, neointimal hiperplazi, deneysel model

Received: 01.06.2020 Accepted: 11.08.2020 Published (Online)29.10.2020:

*Coresponding Authors: Oguz KARAHAN. Medical School of Alaaddin Keykubat University, Department of Cardiovascular Surgery, Antalya, Turkey,+905063929320,oguzk2002@gmail.com

ORCID: 0000-0003-0044-9476

To cited: Karahan O, Ocal N, Sumer T, Hafız E, Khalil E. Vascular compatibility of superelastic stent. Acta Med. Alanya 2020;4(3):236-241. doi:10.30565/medalanya.745576 


\section{Introduction}

$\mathrm{P}$ eripheral vascular diseases can be controlled with either, or a combination of, medical management or lifestyle changes. Usually, medication and lifestyle changes are ineffective in providing enough distal blood flow when a lesion becomes a progressively occlusive degree. In this case, advanced techniques are required, such as interventional or surgical methods [1-3]. Recent advances in percutaneous techniques offer more advantages compared with surgery, such as less operation time, a small and single interventional point, a local anaesthesia solution and simultaneous visualisation. Foreign body reaction, re-occlusion rates and disrupted endothelial structure are the most common disadvantages of interventional techniques. Therefore, new tissuefriendly techniques and compatible products are tried to be developed [3-6].

Vascular stents, one of the important products in the application of percutaneous techniques, have been used for decades to maintain the patency of occluded vessels [6]. Scientists have focused on improving the basic features of metal stents, such as content, coating and braiding design, which can increase tissue compatibility [6-8]. It is thought that these artificial objects, which are well designed and adapted to tissue, may be the vascular technology of the future. All of these technological touches target minimal damage to tissue, sustainability in endothelial functions and reduced thrombogenicity [6-8].

The current study aimed to experimentally investigate the mid-term endothelial patency, six-month endothelial reaction and tissue biocompatibility of the new super elastic braided stents in sheep.

\section{Material and Methods}

After designation of the study steps, ethical approval was obtained from the local animal ethical committee (No. 2018/10-57) of the university. Two healthy female Akkaraman ewes (weighing 35-45 $\mathrm{kg}$ ) were obtained from the laboratory production unit of the university. The animals were kept in 12-hour light/dark-cycle cages programmed with standard humidity $(50 \pm 5 \%)$ and temperature (22 $\pm 2^{\circ} \mathrm{C}$ ). The animals were allowed free access to a standard diet and tap water until study protocols began. All regulations were met throughout the time the experiments were performed in accordance with the Animal Welfare Act and the Guide for the Care and Use of Laboratory Animals.

The first step was applying a general anaesthesia, as described in previous reports [5, 6]. One of the ewes was called stent I and the other stent II (both stents were NoetriX®, Noegenix, Ankara, Turkey) for recording the findings separately. Due to the anatomical condition of iliac arteries in sheep, the external iliac arteries were selected for stent implantation. (The iliac artery does not exist in sheep, and abdominal aorta is bifurcated external and internal iliac arteries directly with a small trunk. External iliac arteries are progressing and is called the deep circumflex artery, which is divided into two branches known as cranial and caudal segments.)

The follow-up duration was determined to be six months for obtaining mid-term results. During this time, acute, sub-acute and late reactions were evaluated. Initially, acute, dermal, vascular and systemic reactions were observed after the stent application. Dermal and intradermal reactions were evaluated with inspections, and any changes were noted. The intravascular evaluation was done by a colour flow Doppler ultrasound (Mindray $®$ DP-20 Vet, Shenzhen, China). Systemic reactions were assessed with vital signs, and any changes were noted. After the six-month follow-up period, the ewes were sacrificed with an overdose intravenous barbiturate injection (Narcoren, Rhone Merieux, Laupheim, Germany).

Implantation of the stents:

The inguinal area of the ewes was shaved and disinfected, and the vascular structures were evaluated with a Doppler ultrasound (Figure 1A, $B)$. An arterial puncture was then made with the Seldinger technique, and a $7 \mathrm{Fr}$ vascular sheath was placed into the femoral arteries of the ewes (Figure 1C). The infusion catheter (GoraN $\AA$, Noegenix, Ankara, Turkey) was progressed to the abdominal aorta and a contrast agent infused from the catheter. During the contrast infusion, $X$-ray radiograms of the groin area were obtained for documenting the vascular anatomy of the ewes (Figure 2A). After determining the anatomy, the 
stent upload was made with a WelaN $₫$ catheter (Noegenix, Ankara, Turkey), and the stents were placed into the external iliac artery with ultrasound guidance (Figure 2B).

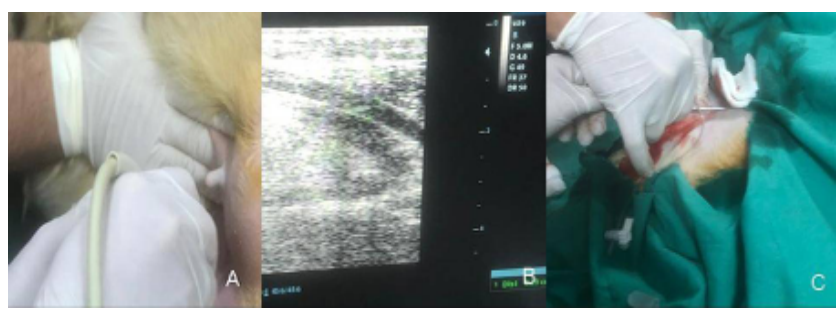

Figure 1 A,B. Ultrasonographically monitoring of sheep iliac artery, C. Puncture of sheep iliac artery with Seldinger technique.

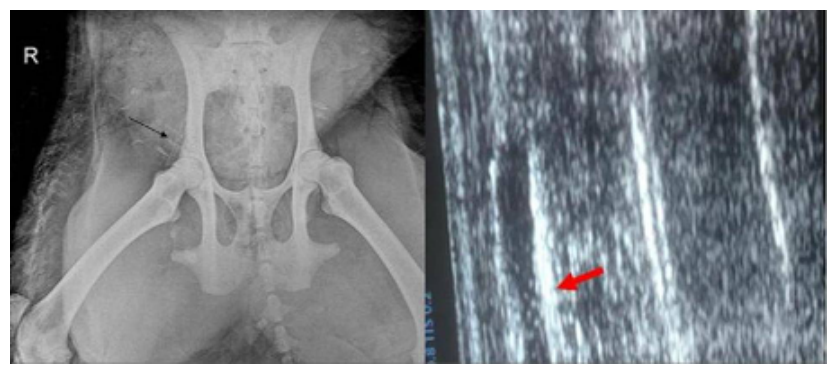

Figure 2 A. Radiograms of placed stent (black arrow), B. Intravascular visualization of stent (red arrow)

\section{Ultrasonography monitoring:}

After implantation of the stents, the vascular flows were periodically evaluated (every two hours on the first day, every six hours on the second day and twice a day thereafter) to determine the early occlusion or thrombosis. During the followup period, all ultrasound evaluations (Mindray ${ }^{\circledR}$ DP-20 Vet Ultrasonography device, Shenzhen, China) were made by the same practitioner. At each assessment, three areas were evaluated and recorded as follows: 1) An area of $5 \mathrm{~mm}$ on the upper side of the stents' proximal aperture; 2) The medial segment; and 3) An area of $5 \mathrm{~mm}$ on the lower side of the stents' distal aperture. Both the distal and proximal aperture areas and the total edge areas were calculated and compared with previous records.

\section{Medication:}

Anticoagulation was provided for the first three months with a daily $2 \times 4000$ IU subcutaneous enoxaparin injection (Oksapar 4000 IU, $4000 \mathrm{IU} / 0,4 \mathrm{ml}$, Koçak Farma, Istanbul, Turkey).
The anticoagulation protocol was stopped at the end of the third month, and the stent patency was evaluated without anticoagulation in the second three-month period.

Histopathological analysis:

After scarification of the animals, normal and stentimplanted vascular tissue biopsies were taken (Figure 3A, B, C). The tissue cytology tests were applied to all the taken samples in accordance with previous reports $[5,6]$. The vascular intimamedia thickness and inflammatory reactions were determined histopathologically.

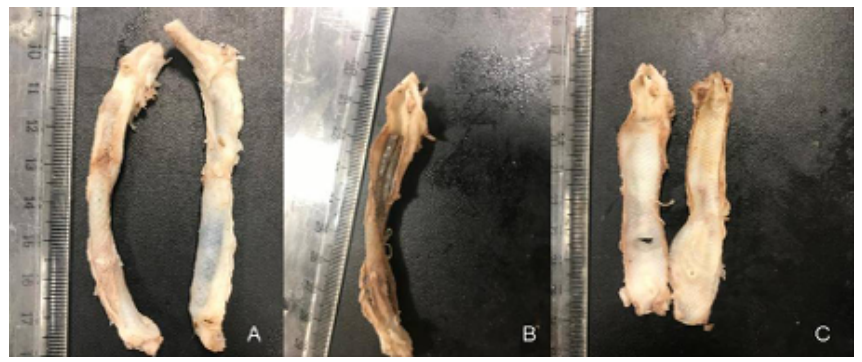

Figure 3 A. External macroscopic visualization of vessel biopsies, B. Internal visualization vessel and implanted stent together in biopsy samples. C. The visualization of endothelial layers in vessel biopsies.

Tissue samples were fixed in $10 \%$ buffered formalin from 48 to 72 hours and washed at topwater for 6 to 8 hours. The tissue samples were then processed into alcohol at different temperatures $\left(70^{\circ}, 80^{\circ}, 90^{\circ}, 96^{\circ}\right.$ and $\left.99.5^{\circ}\right)$ and xylol series for follow-up and embedded into paraffin blocks at 56 to $58{ }^{\circ} \mathrm{C}$. Coronal $4-5 \mu \mathrm{m}$ thick paraffin sections were obtained manually with a microtome. One slice was stained with hematoxylin-eosin (HE) and the other was stained with elastic stain kit (Sigma-Aldrich, USA). All sections were evaluated histopathologically with an Olympus BX51 trinocular light microscope (Olympus Optico Co. Ltd, Tokyo, Japan), and digital micrographs were taken with a DP25 digital camera (Olympus, Tokyo, Japan).

The average lengths of the proximal, medial and distal parts of the lamina elastica and lamina intimae (which contains an endothelial layer) were calculated with image analysis software (Image J v1.46r, National Institute of Health, Bethesda, MD, USA) using a 10X objective. The histopathological findings were evaluated according to endothelisation, existing thrombosis and endothelial and intimal thickening criteria, 
and the obtained data were scored as follows, as described in the previous reports:

Endothelisation:

Score 0: Luminal surface was covered $90 \%$

Score 1: Luminal surface was covered $75 \%$ to $90 \%$

Score 2: Luminal surface

was covered $<75 \%$

Thrombosis:

Score 0: No intraluminal

thrombus formation

Score $1:<5 \%$ intraluminal

thrombus formation

Score $2:<5 \%$ to intraluminal $50 \%$ thrombus formation

Score 3: $>50 \%$ intraluminal

thrombus formation

Leukocyte infiltration: Score 0: No infiltration

Score 1:Slightly

Score 2:Moderate

\section{Results}

During the early implantation period (the first 24 hours) of the stents, acute reactions, such as dermal or intradermal hyperaemia, necrosis, hematoma, bleeding, limping or leg swelling symptoms, were not observed. The systemic findings on the operated ewes were in the normal ranges, and any other finding in favour of systemic toxicity was not detected.

The location of the stents was periodically checked with direct radiograms, and during the observation period migration was not noted. The patency of the stents was evaluated with Doppler ultrasonography. While minimal insignificant intimal thickening $(<0.1 \mathrm{~mm})$ was ultrasonographically detected in stent 1 , progressive neointimal hyperplasia was not detected in the three ultrasound plans. There was no stenosis or occlusion of any segments of the stent-implanted arteries of the experimental models during the six-month observation period.

Complete re-endothelisation was detected in vascular samples from stent $\mathrm{II}$, and the whole stent surface was covered with an endothelial layer. However, endothelisation was was histologically detected as partially incomplete in vascular samples from stent I. Macro or micro thrombosis was not observed in either sheep. While a slight intimal thickening, related to mild neutrophil, leukocyte, and lymphocyte infiltration, was observed in the vascular structure of stent I (Figure 4A, B), intimal thickening and leukocyte infiltration (Table 1) was not observed in stent II (Figure 4C, D). Histological stenosis or occlusion was not detected in either vascular structure.

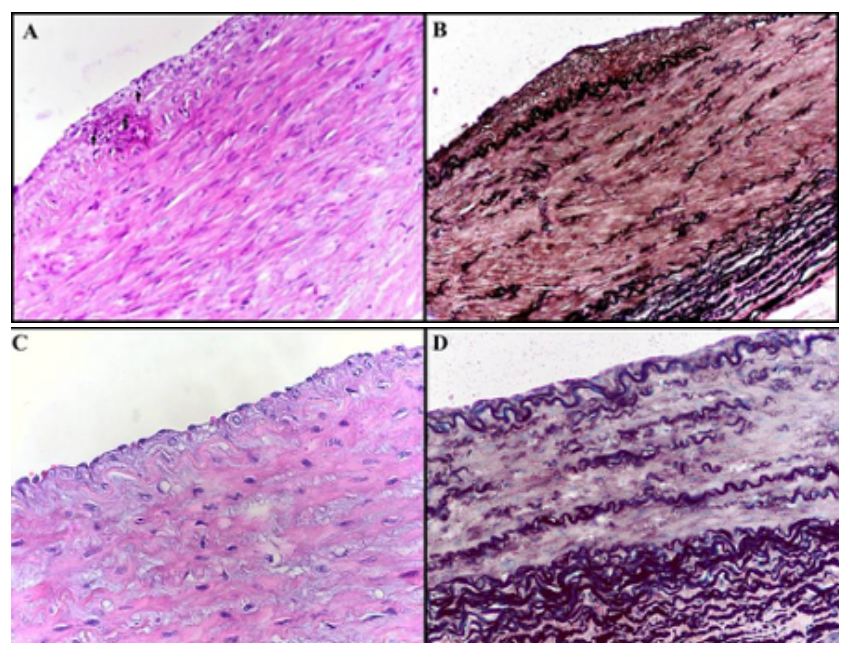

Figure 4: A. Complete endothelial formation, slightly thickened intimal region with mild leukocyte infiltration (arrow), Hematoxylin and Eosin staining, 20x magnifying of stent 1 , B. Internal elastic lamina and elastic fibrils (black / blue-black staining), Elastin staining, 20x magnifying of stent 1, C. Normal intimal layer with competition of intimal layer, Hematoxylin and Eosin staining, 40x magnifying of stent 2, D. Normal internal elastic lamina and elastic fibrils, Elastin staining, 40x magnifying of stent 2 .

Table 1: Histopathologic scoring of stent implanted vessel areas

\begin{tabular}{|l|l|l|l|l|}
\hline & Re-endotelisation & Thrombosis & Leukocyte & $\begin{array}{l}\text { Intimal } \\
\text { Thickening } \\
(\mu \mathrm{m})\end{array}$ \\
\hline Stent1 & 1 & 0 & 1 & 2,59 \\
\hline Stent2 & 0 & 0 & 0 & 3,16 \\
\hline
\end{tabular}

\section{Discussion}

According to our preliminary results, new super elastic stents seem to have good compatibility with the endothelial structure. During the sixmonth follow-up period, marked endothelial damage and associated neointimal hyperplasia were not observed histopathologically. Occlusive or stenotic patterns were also not detected at the 
proximal or distal sites of both stents.

Preventing arterial occlusions is important to avoid disrupted blood flow and impaired endorgan circulation. Continuing blood flow can be provided with interventional or surgical procedures in stenotic or occlusive arterial lesions. Interventional techniques are the least invasive and easiest way to treat these disorders [9]. Balloon and stent angioplasty are the main application types of interventional techniques. The main problem is maintaining vessel patency after these applications. In particular, stent implantation leads to reactions in the vessel wall that can result in re-occlusion [9-11]. Stents have foreign body potential for vascular endothelium and circulating blood cells, and this foreign body triggers thrombosis formation with platelet activation. The other point that contributes to re-stenosis after stent replacement are endothelial reaction and neointimal hyperplasia [10-12]. Therefore, manufacturers are focused on producing bioavailability stents that offer the maximum as possible as it can. Despite the advanced technology, every strategy leads to reactions that can result in less or more vessel occlusion [13, 14]. The main tissue responses can be listed as endothelial hyper-reactivity, platelet adhesion, activation of thrombotic processes and inflammatory events, such as leucocyte recruitment, smooth muscle cell migration and proliferation. These reactions against stents are related to many stent related features, such as the structure, shape, produced material, knitting, size and radial force [13-15]. Initially stents were bare and simple products. Thus, manufacturers tried to find the best combination to obtain minimal tissue response and the longest patency rates. Thereafter, some stent options, such as bare, coated and drug-released stent variants, were produced. While every new development has offered promising results, compared to new derivatives bare stents have always yielded positive data [14-17]. Cejna et al. (2001) compared covered and bare stents in their experimental model and claimed that "the bare stent performed best in regard to neointimal formation and caused the least inflammatory response" [18]. They had a three-month follow-up period and suggested bare stent usage for iliac arteries, in accordance with intravenous ultrasonography and electron microscopy findings [18]. While our followup period was six months, we used the same experimental model as the Cejna et al. study [18]. We only observed the new super elastic braided stent and found a minimal inflammatory response and complete patency during the follow-up period. Ocke Reis et al. (2019) suggested that there are conflicting results on covered and bare stents in iliac artery lesions, and these results need to be clarified with further studies [17]. They added that exact subgroup analyses are insufficient or lesion characteristics can be different in both studies, and the results of this research can be different due to infrastructural differences and insufficient real-world data [17]. Recently, larger trials have presented balanced results. For example, a new study that compared VIABAHN and bare stents in human subjects concluded that both stent types have similar long term results[19]. This study also reported the same mid-term outcomes in patients with iliac artery disease, localisation of lesions and propensity scores [20]. We did not compare bare stents with other types of stent. However, our study involved the longest experimental followup period for bare stents implanted in the iliac arteries of sheep. We found minimal neointimal hyperplasia over six months, and there was no occlusive pattern histopathologically.

Limitations of the study: Firstly, this study presents preliminary results from animals. So, results should be confirmed with human subjects that have pathologically iliac occlusive disease required. Secondly, this study is not a comparative study and may offer one-sided results without comparison of another product.

We concluded that the new super elastic bare stent seems to be safer for iliac arteries with minimal tissue response in animals. However, these findings should be confirmed with human studies.

Financial disclosure: The authors declared that this study has received no financial support.

Conflict of interest: No conflict of interest was declared by the authors.

\section{REFERENCES}

Firnhaber JM, Powell CS. Lower Extremity Peripheral Artery Disease: Diagnosis and Treatment. Am Fam Physician. 2019;99(6):362-369. PMID: 30874413

Sontheimer DL. Peripheral vascular disease: diagnosis and treatment. Am Fam Physician. 2006 ;73(11):1971-6. PMID: 16770929 
3. Pancioli AM. Combination pharmacotherapy for achievement and maintenance of vascular patency. Stroke. 2009:40(3 Suppl):S99-102. DOI: 10.1161/STROKEAHA.108.529800. PMID: 19064809

4. Vorwerk D, Gu"nther RW, Schu"rmann K, Wendt G. Aortic and iliac stenoses: follow- up results of placement after insufficient balloon angioplasty. Radiology 1996; 198:45-48. DOI: 10.1148/radiology.198.1.8539403, PMID: 8539403

5. Schürmann K, Vorwerk D, Uppenkamp R, Klosterhalfen B, Bu"cker A, Gu“nther RW. Iliac arteries: plain and heparin-coated Dacron-covered stent-grafts compared with noncovered metal stents-an experimental study. Radiology 1997; 203:55-63. DOI: 10.1148/radiology.203.1.9122416, PMID: 9122416

6. Schürmann K, Lahann J, Niggemann P, Klosterhalfen B, Meyer J, Kulisch A, et al., Biologic response to polymer-coated stents: in vitro analysis and results in an iliac artery sheep model. Radiology. 2004;230(1):151-62. DOI: 10.1148/radiol.2301021071, PMID: 14645877

7. Lineberger CK, Robertson KM. Vascular stenting. Curr Opin Anaesthesiol. 2002;15(1):37-44. DOI: 10.1097/00001503-200202000-00006, PMID: 17019182

8. Tomberli B, Mattesini A, Baldereschi GI, Di Mario C. A Brief History of Coronary Artery Stents. Rev Esp Cardiol (Engl Ed). 2018;71(5):312-319. DOI: 10.1016/j. rec.2017.11.022, PMID: 29361499

9. Alt E, Haehnel I, Beilharz C, Prietzel K, Preter D, Stemberger A, et al., Inhibition of neointima formation after experimental coronary artery stenting: a new biodegradable stent coating releasing hirudin and the prostacyclin analogue iloprost. Circulation. 2000;101(12):1453-8. DOI: 10.1161/01.cir.101.12.1453, PMID: 10736292

10. Ishikawa O, Tanaka M, Konno K, Hasebe T, Horikawa A, lijima A, et al., Swine model of in-stent stenosis in the iliac artery evaluating the serial time course. Exp Anim. 2018 Nov 1;67(4):501-508. doi: 10.1538/expanim.18-0027. DOI: 10.1538/ expanim.18-0027, PMID: 30068792

11. Dolmatch B, Dong YH, Heeter Z. Evaluation of three polytetrafluoroethylene stentgrafts in a model of neointimal hyperplasia. J Vasc Interv Radiol. 2007;18(4):52734. DOI: 10.1016/j.jvir.2007.02.011, PMID: 17446544

12. 12.Edwards JM, Alloosh MA, Long XL, Dick GM, Lloyd PG, Mokelke EA, et al., Adenosine $A 1$ receptors in neointimal hyperplasia and in-stent stenosis in Ossabaw miniature swine. Coron Artery Dis. 2008;19(1):27-31. DOI: 10.1097/MCA.0b013e3282f262b4, PMID: 18281812

13. Schürmann K, Vorwerk D, Bücker A, Grosskortenhaus S, Günther RW. Single and tandem stents in sheep iliac arteries: is there a difference in patency? Cardiovasc
Intervent Radiol. 1998;21(5):411-8. DOI: 10.1007/s002709900289, PMID: 9853148

14. Sun S, Beitler JJ, Ohki T, Calderon TM, Schechner R, Yaparpalvi R, et al., Inhibitory effect of brachytherapy on intimal hyperplasia in arteriovenous fistula. J Surg Res. 2003;115(2):200-8. DOI: 10.1016/s0022-4804(03)00253-1, PMID: 14697284

15. Zain MA, Siddiqui WJ. Neointimal Hyperplasia. In: StatPearls. Treasure Island (FL): StatPearls Publishing; 2018. http://www.ncbi.nlm.nih.gov/books/NBK499893/. Accessed Jan 2020. PMID: 29763068

16. Collins MJ, Li X, Lv W, Yang C, Protack CD, Muto A, et al., Therapeutic strategies to combat neointimal hyperplasia in vascular grafts, Expert Rev Cardiovasc Ther. 2012;10(5):635-47. DOI: 10.1586/erc.12.33, PMID: 22651839

17. Ocke Reis PE, Behrendt CA. Covered Versus Bare-metal Stents for lliac Occlusive Disease. J Vasc Endovasc Therapy 2019; 4(3):15

18. Cejna M, Virmani R, Jones R, Bergmeister H, Losert $\mathrm{U}, \mathrm{Xu} Z$, et al. Biocompatibility and performance of the Wallstent and several covered stents in a sheep iliac artery model. J Vasc Interv Radiol. 2001;12(3):351-8. DOI: 10.1016/s1051. 0443(07)61916-2, PMID: 11287514

19. Geraghty PJ, Mewissen MW, Jaff MR, Ansel GM; VIBRANT Investigators. Threeyear results of the VIBRANT trial of VIABAHN endoprosthesis versus bare nitino stentimplantation for complex superficial femoral artery occlusive disease. J Vasc Surg. 2013 ;58(2):386-95.e4. DOI: 10.1016/j.jvs.2013.01.050,PMID: 23676191

20. Piazza M, Squizzato F, Dall'Antonia A, Lepidi S, Menegolo M, Grego F, et al. Editor's Choice - Outcomes of Self Expanding PTFE Covered Stent Versus Bare Metal Stent for Chronic lliac Artery Occlusion in Matched Cohorts Using Propensity Score Modelling. Eur J Vasc Endovasc Surg. 2017;54(2):177-185. DOI: 10.1016/J. ejvs.2017.03.019, PMID: 28487112 